\title{
Theater in education at Ho Chi Minh City Open University in Vietnam: Students' awareness of benefits and challenges in English and American literature classes
}

\author{
Le Quang Truc ${ }^{1 *}$ \\ ${ }^{1}$ Ho Chi Minh City Open University, Vietnam \\ *Corresponding author: truc.leq@ou.edu.vn
}

ARTICLE INFO

DOI:10.46223/HCMCOUJS.

soci.en.9.1.269.2019

Received: June $19^{\text {th }}, 2019$

Revised: July $16^{\text {th }}, 2019$

Accepted: July $17^{\text {th }}, 2019$

Keywords:

beneficial effects, drama project, foreign language, students, theater in education
ABSTRACT
This study examined whether the students participating in the drama program "THEATER IN EDUCATION: English and American Literature Classes' Performances, 2017' at Ho Chi Minh City Open University in Vietnam perceived the benefits and challenges of the Theater in Education method as demonstrated in previous research in the field of foreign language learning. The data needed was collected by means of a questionnaire that consisted of seven questions. Similarities and differences between the findings of the study and what had been reported in previous research studies were then discussed. Hopefully, this study is informative for those interested in the adoption of the Theater in Education method in foreign literature classes at the faculty of foreign languages of a university.

\section{Introduction}

In the first semester of the academic year 2017-2018, I taught two classes of English Literature and two classes of American Literature at the Faculty of Foreign Languages of Ho Chi Minh City Open University (HCMCOU). With the Theater in Education method introduced at the beginning of the semester and freedom given in choosing the way to study, all the 124 students in my four classes decided to complete their courses by implementing this method rather than with traditional learning that would entail presentations and essay writing they had been used to in the literature classes of their secondary education. They divided themselves into ten groups and selected ten literary works to stage: And Then There Were None by Agatha Christie, A Christmas Carol by Charles Dickens, Me Before You by Jojo Moyes, Jane Eyre by Charlotte Brontë, Pride and Prejudice by Jane Austen, My Sister's Keeper by Jodi Picoult, Lolita by Vladimir Nabokov, The Help by Kathryn Stockett, A Little Princess by Frances Hodgson Burnett, Psycho by Robert Bloch. Their tremendous efforts resulted in the ten audience-captivating plays successfully performed at the Drama Theater of Ho Chi Minh City on 02, 09, 15, 16, and 23 December 2017 in the five-night Theater in Education program named "THEATER IN EDUCATION: English and American Literature Classes' Performances, 2017 ". Evidently, all the students participating in the program were very excited with what they experienced as their excitement kept emerging in the waves of joyful posts on their Facebook 
accounts with numerous pictures of their prop making, rehearsals, scenes on the stage, etc. that lasted for such a long time prior to and after their public performances (Facebook is a very popular social network in Vietnam). Having gained theoretical knowledge from personal research on the benefits and challenges of the Theater in Education method and first-hand experiences with the previous Theater in Education seasons beforehand, I did not lecture on them at the beginning of the semester so as to let my students make a decision on what way to learn simply with their imagination and expectation after listening to my descriptions of what to do and how to work in the introduction to the Theater in Education method and previous generation students' in casual conversations prior to the semester. After the students had finished the challenging but exciting journeys with the completion of their public performances at the theater, however, I had them reflect on the itinerary they had gone through to see the fruitfulness they had harvested as well as the difficulties they had encountered. In this way, I conducted testing research where I could compare and contrast my students' perceptions of the advantages and disadvantages of the use of the Theater in Education method in their own contexts with what had been widely recorded of those merits and issues in applying this method in teaching and learning foreign languages.

\section{Literature review}

This study is based upon a basic notion of the Theater in Education method in language learning and a review of the existing literature on the use of drama in foreign language teaching, in general, and that of the drama project or the Theater in Education method, in particular.

\section{Basic notion of Theater in Education method in language teaching}

In language teaching, "Theater in Education", in a nutshell, refers to a working method that helps a group of students learn the target language by enjoying plays performed by professional actors or participating in a drama project with the assistance of a company of drama experts (Šmardová, 2008). The final Theater in Education production of the drama project is a public performance with educational values that can take place either at school or at a theater (Dodson, 2000; Šmardová, 2008).

\section{Benefits of the drama project or the Theater in Education method in foreign language teaching}

With the empirical studies that prove the beneficial impacts of the use of drama in teaching foreign languages, it has been reported that the benefits of using drama in teaching foreign languages are remarkable, and sometimes unforeseen (Giebert, 2014). Drama used in a foreign language class can help the students not only learn the target language but also develop their personal values (Boudreault, 2010). What the students gain from the utilization of drama in their foreign language learning are of various aspects: language, social competencies, psychology, social life, individual talents/interests and creativity.

First of all, with a drama project, the students develop their linguistic knowledge and skills (Wessels, 1987; Whiteson, 1996). Working with a ready-made play or a literary work or a movie they choose to adapt into a play, the students build up their understanding of grammar and vocabulary (Giebert, 2014) and improve their reading skills (Fonio \& Genicot, 2011). They also enhance their writing in producing the script (Fonio \& Genicot, 2011), the brochure, and promotional texts for their play (Giebert, 2014). During the rehearsals, they learn, in practice, speaking with correct pronunciation and intonation (Fonio \& Genicot, 2011). 
In the second place, the students have an opportunity to appreciate the cultural features in the play (Gualdron \& Castillo, 2018). As a result, they advance their intercultural competence (Marjanovic-Shane, 1997) that enriches their interpersonal communication. Another social competence the students have a chance to train is effective teamwork. When they are responsible for their own learning and for the success of the whole play (Ronke, 2004; Scheutz \& Colangelo, 2004), the students have not only personal goals to achieve but also common goals to put on a good final production together (Ronke, 2004). For that reason, they must learn to connect well to build a strong community by helping one another with a strong awareness of responsibility (Gualdron \& Castillo, 2018). Thus, teamwork is learned and established for them to be well prepared for any working environment in society that demands cooperation and collaboration (Carson, 2012). Moreover, empathy, one more social competence that cultivates humanity, grows when the students explore and act the fictional characters of the play (Giebert, 2014).

Thirdly, involved in a Theater in Education program, the students arrive at the feeling of motivation and pride with greater confidence and self-esteem (Ronke, 2004) since the final production gives individual participants either a tremendous sense of accomplishment and satisfaction or a heightened awareness of their potential to do the improbable (Ronke, 2004; Scheutz \& Colangelo, 2004; Yoshida, 2007). Their psychological development is affected in a positive manner that way (Marjanovic-Shane, 1997; Scheutz \& Colangelo, 2004).

Fourthly, the participants usually establish friendships that make their social lives more colorful and meaningful (Šmardová, 2008) with a learning process that is enjoyable (Boudreault, 2010; Wessels, 1987). The learning is made memorable with its constant interactivity (Boudreault, 2010) that brings about the considerable joy (Wessels, 1987).

Finally, the students have a chance to display and advance their individual talents or interests when joining a drama project that requires diverse specialist knowledge and skills. Individuals who have different passions, special abilities or aptitudes, and inclinations or hobbies make a contribution to the outcome of the group work in different areas: administration, writing, marketing, logistics, acting, make-up, hair styling, costumes, audio-visual effects, music, props, etc. (Boudreault, 2010; Giebert, 2014). To fulfill their tasks, the students must exploit their imagination and thus their creativity is fostered (Ronke, 2004; Scheutz \& Colangelo, 2004) when they are learning actively in a creative approach (Giebert, 2014).

\section{Challenges of the drama project or the Theater in Education method in foreign language teaching}

In spite of the above-mentioned outstanding merits, the Theater in Education method or the drama project is reportedly confronted with some challenges. Those challenges arise from three determinants: the teacher, the students, and the workload.

To begin with, one of the requisites for the stage production of the drama project or the Theater in Education method is the carefully detailed preparation of the teacher in charge (Yoshida, 2007). Nevertheless, in practice, whereas the use of drama in language teaching requires the teacher involved enthusiasm and meticulosity (Wessels, 1987) in organizing various activities (Šmardová, 2008) and keeping the students constantly stimulated (Wessels, 1987), numerous language teachers are not willing to employ drama in their teaching (Wessels, 1987) as they are not confident to exercise a teaching method they have not been familiarized with or trained in (Gaudart, 1990; Giebert, 2014; Royka, 2002). 
On the students' side, while the drama project or the Theater in Education method is supposed to be efficiently utilized only with a group of volunteer students, not every student immediately finds it useful. Therefore, a number of students are likely to be not motivated or ready to take part in the project with their skepticism (Šmardová, 2008). Those skeptical students will not be convinced of its beneficial effects until they have witnessed the success and progress the volunteer students have made (Wessels, 1987). Even for those volunteer students who ensure dedication and loyalty to the final production of the project, conflicts are unavoidable when they work together (Carson, 2012).

The last issue is the workload. The drama project necessitates a heavier workload for both the teacher in charge and the students involved (Nha, 2009). On the one hand, it is timeintensive for the teacher (Wessels, 1987). On the other hand, for the achievement of the final goal of the project, the students are supposed to put more effort into their work as they have to work harder and longer hours than in a regular language class (Ronke, 2004). In addition, the students are to bear the annoyance of the corrections of their mispronunciations and the repetitions of the lines of the characters they act during the rehearsals (Fonio \& Genicot, 2011).

\section{Research methodology}

\section{Research question}

The purpose of this study was to find out the answer to the following question:

Did the students participating in the drama program "THEATER IN EDUCATION: English and American Literature Classes' Performances, 2017" at HCMCOU in Vietnam perceive the benefits and challenges of the use of the Theater in Education method as demonstrated in previous research in the field of foreign language learning?

\section{Participants}

The participants of this study were 121 students who took part in the program "THEATER IN EDUCATION: English and American Literature Classes' Performances, 2017" that was held at the Drama Theater of Ho Chi Minh City in December 2017, including the students enrolled in my classes of English Literature and American Literature of the Faculty of Foreign Languages at HCMCOU who majored in English and the outsiders taking part in the program who were my students' friends.

\section{Instrument}

The data for this descriptive study was collected by means of a questionnaire that had seven items designed to elicit the needed information from the participants as follows:

QUESTIONNAIRE FOR RESEARCH ON “THEATER IN EDUCATION: English and American Literature Classes' Performances, 2017",

1. Were you a student enrolled in the English/American literature course or an outsider engaged in "THEATER IN EDUCATION: English and American Literature Classes' Performances, 2017"? (Put a check next to the answer relevant to your situation.)

a. I was a student enrolled in the English/ American literature course.

b. I was an outsider engaged in the program. 
2. If you were an outsider, answer the two questions below. (Skip over this item if you were a student enrolled in the English/American literature course.)

a. What was your occupation?

b. Why were you engaged in the program?

3. What was your task in the production of the play of your group?

4. What difficulties or challenges were you confronted with? How did you deal with the difficulties or challenges you were faced with?

5. What have you gained through participating in the program?

a. Knowledge and skills in English language learning:

b. Knowledge and skills in other fields than English language:

c. Psychology:

d. Social life:

e. Others:

6. Would you recommend this program for the following generation students of the Faculty of Foreign Languages at Ho Chi Minh City Open University? (Check the answer you choose.)
a. Yes
b. No

7. Would you like to give more personal comments on the program apart from the answers to the questions above? (Write as many comments as you wish to.)

Two of the seven items (items 1 and 6) were selected-response and the remaining (items 2, 3, 4, 5, and 7) open-ended. All the items were numbered and the sub-items lettered. The instructions to navigate the respondents through items $1,2,6$, and 7 were in the imperative to ensure an interactive style for holding the respondents' interest.

\section{Data collection and analysis}

Three months after the completion of the program "THEATER IN EDUCATION: English and American Literature Classes' Performances, 2017”, in early April 2018, 128 copies of the designed questionnaire were sent to all those having participated in the program. Out of the 128 copies of the questionnaire form delivered, 121 were returned while seven were not. The interval between the end of the program and the survey was purposeful in that the participants were allowed sufficient time to recognize the lasting effects of their involvement in the program in reflecting on it with their responses. Thus, superficial thinking would be filtered.

It took one month to collect the 121 completed questionnaires out of the 128 questionnaires delivered. Among the total 121 completed questionnaires returned, one was invalid because of its internal inconsistency and another had an invalid response due to the unintelligible answer to the "Social life" part in question 5. The use of the questionnaire with a 
lack of opportunity for the respondents to have issues clarified led to the misplacement of the information in a number of responses. The misplaced information was edited by inference. The data was then analyzed manually with the help of the Excel spreadsheet program.

\section{Findings}

\section{Responses to questions 1 and 2}

Question 1: Were you a student enrolled in the American/English literature course or an outsider engaged in "THEATER IN EDUCATION: English and American Literature Classes' Performances, 2017”?

a. I was a student enrolled in the English/ American literature course.

b. I was an outsider engaged in the program.

Question 2: If you were an outsider, answer the two questions below. (Skip over this item if you were a student enrolled in the English/American literature course.)

a. What was your occupation?

b. Why were you engaged in the program?

\section{Table 1}

Categories of participants

\begin{tabular}{|l|c|c|}
\hline \multicolumn{1}{|c|}{ Category of participant } & Number & Percentage \\
\hline Outsider & 4 & $3 \%$ \\
\hline $\begin{array}{l}\text { Students enrolled in the American/English Literature } \\
\text { course }\end{array}$ & 117 & $97 \%$ \\
\hline
\end{tabular}

Source: The researcher's data analysis

Table 2

Outsiders' occupations

\begin{tabular}{|c|c|c|}
\hline Occupation & Number & Percentage \\
\hline Student & 4 & $100 \%$ \\
\hline
\end{tabular}

Source: The researcher's data analysis

Table 3

Reasons for outsiders' participation

\begin{tabular}{|c|c|c|}
\hline \multicolumn{1}{|c|}{$\begin{array}{c}\text { Reasons for outsiders' } \\
\text { participation }\end{array}$} & Number of outsiders & Percentage \\
\hline $\begin{array}{l}\text { Acceptance of friend's } \\
\text { invitation }\end{array}$ & 4 & $100 \%$ \\
\hline
\end{tabular}

Source: The researcher's data analysis 
As can be seen in Tables 1, 2, and 3, besides 117 students enrolled in English and American Literature courses that accounted for $97 \%$ of the respondents, there were 4 outsiders making up 3\% who were all students from other universities in Ho Chi Minh City and who took part in the program to accept their friends' invitations. Since the students in my classes were given the freedom to do the grouping and allowed to invite outsiders to join their projects, each class divided themselves into as many groups as they wished to and each group sought as much outside assistance as they needed when the members of the group could not cover all the tasks. That is the reason why there was the presence of these four outsiders who were friends of the students enrolled in the English and American Literature courses at the Faculty of Foreign Languages of HCMCOU. The further details provided in the responses to the first part of question 2 revealed that two of the outsiders also majored in English, whereas the other two did not.

\section{Responses to question 3}

Question 3: What was your task in the production of the play of your group?

\section{Table 4}

Tasks and numbers of task doers

\begin{tabular}{|l|c|c|}
\hline \multicolumn{1}{|c|}{ Task } & Number of task doers & Percentage of task doers \\
\hline Actor & 81 & $67 \%$ \\
\hline Script developer & 30 & $25 \%$ \\
\hline Music and sound designer & 10 & $8 \%$ \\
\hline Prop assistant & 39 & $32 \%$ \\
\hline Make-up assistant & 5 & $4 \%$ \\
\hline Photography assistant & 10 & $8 \%$ \\
\hline Promotional campaign runner & 38 & $31 \%$ \\
\hline Secretary & 14 & $12 \%$ \\
\hline Leader & 10 & $8 \%$ \\
\hline
\end{tabular}

Source: The researcher's data analysis

According to Table 4, two-thirds of the participants (81 out of 121) were actors making the largest number of task doers up to $67 \%$. Actually, every play needed many actors to take the roles of its characters and the ten plays of the program required more than 81 actors. Nevertheless, since a number of students registered both the American Literature and the English Literature courses in that same semester, a certain respondent who had acted two characters in two plays of two classes or/and two different characters in different scenes of the same play was just counted as an actor. On the contrary, the smallest number of task doers was the make-up assistants with five students accounting for only $4 \%$ of the participants because many girls could do the make-up for themselves and for one or two more members of the cast of their play and thus not many make-up assistants were needed.

Nearly equal were the number of prop assistants who designed the props and managed 
them as backstage staff through the rehearsals and performances and that of promotional campaign runners who marketed the plays with 39 and 38 participants accounting for $32 \%$ and $31 \%$ respectively. These numbers were closely followed by the number of script developers with 30 students accounting for $25 \%$.

As every group of the ten had only one leader, one photography assistant who was in charge of images for the promotion, the poster, and the behind-the-scenes material, one music and sound designer who selected and played the music and sound effects for their play, the numbers of these categories of task doers were ten each. Differently, the number of secretaries was 14 because some groups had each more than one secretary.

\section{Table 5}

Number of tasks per person and number of task doers

\begin{tabular}{|c|c|}
\hline Number of tasks per person & Number of task doers \\
\hline 1 & 44 \\
\hline 2 & 44 \\
\hline 3 & 23 \\
\hline 4 & 8 \\
\hline 5 & 2 \\
\hline
\end{tabular}

Source: The researcher's data analysis

Unlike Table 4 that reflects the various tasks the participants undertook, Table 5 represents their commitment to the project they joined in. Whereas only about one-third of the participants took on one task per person, the rest attended to more than one. Equal to the number of the participants doing one task, approximately another one-third were responsible for two tasks and nearly half this number applied themselves to three tasks. Exceptionally, eight participants busied themselves with four tasks and two threw themselves into five tasks.

\section{Responses to question 4}

Question 4: What difficulties or challenges were you confronted with? How did you deal with the difficulties or challenges you were faced with?

\section{Table 6}

Challenges confronted

\begin{tabular}{|l|c|}
\hline \multicolumn{1}{|c|}{ Challenge/Difficulty confronted } & Number of respondents \\
\hline Arguments/Disagreements in group & 50 \\
\hline Time arrangement for group work & 32 \\
\hline Acting & 31 \\
\hline Pronunciation & 24 \\
\hline Idea negotiation & 13 \\
\hline Intonation & 13 \\
\hline Prop making & 13 \\
\hline Script editing & 11 \\
\hline None & 01 \\
\hline
\end{tabular}

Source: The researcher's data analysis 
The challenges or difficulties the participants were confronted with are presented in Table 6. Disagreements or arguments between members in the group were the biggest problem reported by slightly less than half of the participants. Came second time arrangement for group work and acting which were almost equally given an account of by one-fourth of them. Onefifth gave an account of difficulties in pronunciation while idea negotiation in group discussions, intonation, prop making, and script editing was each mentioned by around onetenth of the respondents.

\section{Table 7}

Problem-solving strategies

\begin{tabular}{|l|c|}
\hline \multicolumn{1}{|c|}{ Problem-solving strategy } & Number of respondents \\
\hline Group discussion & 65 \\
\hline $\begin{array}{l}\text { More practice (work harder and longer hours } \\
\text { with friends and individually) }\end{array}$ & 23 \\
\hline Reorganization of individual schedule & 18 \\
\hline Help from teacher & 11 \\
\hline Help from director & 5 \\
\hline
\end{tabular}

Source: The researcher's data analysis

Table 7 reveals four trends in the participants' solutions to the problems they faced. The first strategy they deployed was to take advantage of group work by group discussion. They discussed the different ideas and came to the final decisions agreed on by all the members. This strategy was acknowledged by 65 participants, more than half of them. Second, 23 participants practiced acting and speaking the characters' lines more outside the class time, either in a group or individually. Third, they made personal efforts by reorganizing their individual schedules to make time for group meetings and rehearsals. Eighteen participants disclosed this practice. Finally, they asked for help from the teacher and the director. Sixteen participants mentioned this strategy in their responses.

\section{Responses to question 5}

Question 5: What have you gained through participating in the program?

a. Knowledge and skills in English language learning

What the participants gained in learning English through participating in the program are described in Table 8. Five respondents left this part unanswered and three asserted they had learned little or nothing of English language. Meanwhile, half the respondents announced they had improved their pronunciation and speaking (63 and 60 respectively). While twenty-six participants affirmed vocabulary learning, improvement in intonation and that in writing were both maintained by the same number of respondents of eighteen. Thirteen of the participants stated they had bettered their listening competence and ten believed they had learned grammar in practice. The English language skill that was thought to have been learned by the least number of respondents is reading with seven answerers writing about it. 


\section{Table 8}

Improvements in English language learning

\begin{tabular}{|l|c|}
\hline Knowledge and skills in English language learning & Occurrences of recognition \\
\hline Pronunciation & 63 \\
\hline Speaking & 60 \\
\hline Vocabulary & 26 \\
\hline Intonation & 18 \\
\hline Writing & 18 \\
\hline Listening & 13 \\
\hline Grammar & 10 \\
\hline Reading & 7 \\
\hline Question left unanswered & 5 \\
\hline Little/None & 3 \\
\hline
\end{tabular}

Source: The researcher's data analysis

b. Knowledge and skills in other fields

\section{Table 9}

Development of knowledge and skills in other fields

\begin{tabular}{|l|c|}
\hline \multicolumn{1}{|c|}{ Knowledge and skills } & Occurrences of recognition \\
\hline Group work & 97 \\
\hline Communication & 50 \\
\hline Acting & 31 \\
\hline Literature appreciation & 31 \\
\hline Time management & 29 \\
\hline Marketing & 17 \\
\hline Problem solving & 12 \\
\hline Critical thinking & 11 \\
\hline Theatrical knowledge & 10 \\
\hline Handy craft making & 8 \\
\hline Question left unanswered & 3 \\
\hline Little/None & 2 \\
\hline
\end{tabular}

Source: The researcher's data analysis

Table 9 indicates knowledge and skills the participants gained in other fields than English language learning. Two respondents held that they learned nothing or so and three left this part unanswered, but the rest listed ten factors. Came first group work with most responses (97) and second communication with less than half of the responses (50). Acting, literature appreciation, time management were each noted by some one-fourth of the participants $(31,31$, and 29 respectively). Over one-tenth of the respondents (17) reported their learning of marketing (there was a promotional campaign for each play). Problem-solving, critical thinking, and theatrical knowledge were each said to be learned in around one-tenth of the questionnaires $(12,11$, and 10 respectively). Held to have been learned by eight participants, the smallest number of the respondents, was handy craft making. 
c. Psychological effects

Table 10

Effects on psychology

\begin{tabular}{|l|c|}
\hline \multicolumn{1}{|c|}{ Psychological effects } & Occurrences of recognition \\
\hline Temper and emotion control & 33 \\
\hline Confidence & 25 \\
\hline Strength to work under pressure & 21 \\
\hline Pride & 8 \\
\hline Motivation & 6 \\
\hline Question left unanswered & 25 \\
\hline None & 2 \\
\hline
\end{tabular}

Source: The researcher's data analysis

The participants' perceptions of beneficial effects on their psychology are summarized in Table 10. Besides 25 respondents leaving this part of question 5 unanswered and two respondents finding no benefits, the others recognized four noteworthy assets. Firstly, temper and emotion control trained in working with others in group work was valued by 33 respondents, more than one-fourth of the total 121. Besides, confidence that was acknowledged by 25 participants, over one-sixth of the respondents, was closely followed by strength to work under pressure perceived by 21 respondents, slightly above one-sixth. Finally, eight participants noticed the growth of pride in themselves and six felt motivated with the involvement in the program.

d. Social life

\section{Table 11}

Effects on social life

\begin{tabular}{|l|c|}
\hline \multicolumn{1}{|c|}{ Effects on social life } & Occurrences of recognition \\
\hline Enjoyable learning experience & 73 \\
\hline Expansion of relationships & 56 \\
\hline Better behavior & 11 \\
\hline Strengthening existing relationships & 6 \\
\hline Question left unanswered & 17 \\
\hline Invalid answer & 01 \\
\hline
\end{tabular}

Source: The researcher's data analysis

Table 11 expresses the effects on the participants' social lives. One participant gave an invalid answer to this second last part of question 5 as the response was unintelligible and seventeen respondents left this part unanswered. Less than two-thirds of the respondents (73 out of 121) had positive comments on an enjoyable learning experience with such expressions as memorable, interesting, fascinating, most meaningful time, to name but a few. In the second place, the expansion of relationships was repeated by 56 respondents, slightly less than half of the total, while the strengthening of their existing relationships was mentioned least in six responses. In the middle came the recognition of better behavior that was identified by eleven respondents. 
e. Others

\section{Table 12a}

Provision of answers to question 5e

\begin{tabular}{|l|c|}
\hline \multicolumn{1}{|c|}{ Provision of answer } & Number \\
\hline Question left unanswered & 92 \\
\hline Question answered & 29 \\
\hline
\end{tabular}

Source: The researcher's data analysis

Table 12a points out three-quarters of the participants (92 out of 121) left this very last part of question 5 unnoted; however, the rest with 29 respondents provided a body of expressions that specify the other values they had attained.

\section{Table 12b}

Other values achieved

\begin{tabular}{|l|c|}
\hline \multicolumn{1}{|c|}{ Expressions of other values attained } & Rate of frequency \\
\hline changing perception, enthusiasm, soft skills & 4 \\
\hline work management, empathy, humanity understanding & 3 \\
\hline $\begin{array}{l}\text { creativity, imagination forming, knowledge of verbal behavior in } 18^{\text {th }} \\
\text { century, character empathy, modesty, changing attitude }\end{array}$ & 2 \\
\hline $\begin{array}{l}\text { knowledge of culture, translating skills, better ideas expression in } \\
\text { English, computer skills, body language, music appreciation, video } \\
\text { editing, designing skills, knowledge of technical field, } \\
\text { meticulousness, leadership skills, psychology understanding, } \\
\text { memorizing, history knowledge, multitasks handling, using music } \\
\text { software, totally new experience, professional working style, } \\
\text { navigation skills, sewing skills }\end{array}$ & \\
\hline
\end{tabular}

Source: The researcher's data analysis

Table $12 \mathrm{~b}$ is the organization, based on the rates of frequency, of the expressions of the other values the respondents listed after having identified what they had gained in connection with English language learning, knowledge and skills in other fields, psychology, and social life. Repeated the most frequently, four times, were three expressions: changing perception, enthusiasm, and soft skills (this expression indeed covers many other values recorded in the answers to the previous parts of question 5). Next, another three expressions were found three times: work management, empathy, humanity understanding. Written twice in the completed questionnaires were the following expressions: creativity, imagination forming, knowledge of verbal behavior in $18^{\text {th }}$ century, character empathy, modesty, and changing attitude. Seen only once in the responses were the expressions of a long list as follows: knowledge of culture, translating skills, better ideas expression in English, computer skills, body language, music appreciation, video editing, designing skills, knowledge of technical field, meticulosity, 
leadership skills, psychology understanding, memorizing, history knowledge, multitasks handling, using music software, totally new experience, professional working style, navigation skills, and sewing skills.

\section{Responses to question 6}

Question 6: Would you recommend this program for the following generation of students of the Faculty of Foreign Languages at HCMCOU?

\section{Table 13}

Recommendation to continue the Theater in Education method for following generation students

\begin{tabular}{|l|c|c|}
\hline Answer & Number & Percentage \\
\hline Yes & 115 & $95.83 \%$ \\
\hline No & 3 & $2.5 \%$ \\
\hline Question left unanswered & 2 & $1.67 \%$ \\
\hline
\end{tabular}

Source: The researcher's data analysis

Table 13 shows that while the application of the Theater in Education method was not recommended for the following generation students at the Faculty of Foreign Languages of HCMCOU by three respondents accounting for $2.5 \%$ and was not given either recommendation or rejection by 2 respondents accounting for $1.67 \%$, it was highly recommended by most of the participants (115 recommendations making up $95.83 \%$ of the total responses).

\section{Responses to question 7}

Question 7: Would you like to give more personal comments on the program apart from the answers to the questions above? (Write as many comments as you wish to.)

\section{Table 14}

Provision of answers to question 7

\begin{tabular}{|l|c|}
\hline \multicolumn{1}{|c|}{ Provision of answer } & Number \\
\hline Question left unanswered & 35 \\
\hline Question answered & 86 \\
\hline
\end{tabular}

Source: The researcher's data analysis

Table 14 displays the provision of answers to question 7. When it came to question 7 , more than one-quarter of the respondents left the question unanswered, yet approximately threequarters provided their answers with two negative comments that were outweighed by a larger number of positive ones and a number of suggestions for future Theater in Education programs. 


\section{Table 15}

Negative comments in responses to question 7

\begin{tabular}{|l|c|}
\hline \multicolumn{1}{|c|}{ Expression of negative comments } & Rate of frequency \\
\hline Too time consuming & 1 \\
\hline Stressful & 1 \\
\hline
\end{tabular}

Source: The researcher's data analysis

Table 15 specifies two negative comments in the responses to question 7. One respondent complained that the use of the Theater in Education method was too time consuming and the other criticized that it was stressful.

\section{Table 16}

Positive comments in responses to question 7

\begin{tabular}{|l|c|}
\hline \multicolumn{1}{|c|}{ Expressions of positive comments } & Rate of frequency \\
\hline unique experience & 16 \\
\hline appreciate & 14 \\
\hline practical benefits found & 6 \\
\hline develop soft skills & 5 \\
\hline social life developed & 4 \\
\hline new things to learn & 3 \\
\hline educational, great diversity of play genres & 2 \\
\hline $\begin{array}{l}\text { outsiders can join and be treated well, } \\
\text { voluntary activity, creative, an extremely } \\
\text { useful playground }\end{array}$ & \\
\hline $\begin{array}{l}\text { increasingly attractive, significant, more } \\
\text { mature thoughts, get experienced, learn how } \\
\text { to work carefully, more open-minded, } \\
\text { positive thinking way }\end{array}$ & \\
\hline
\end{tabular}

Source: The researcher's data analysis

Table 16 is a collection of various expressions that conveyed positive comments on the Theater in Education program the participants experienced and their rates of frequency in the responses to question 7. Repeated more than ten times were five expressions: unique experience, appreciate, good opportunity to learn, memorable, most meaningful time. Furthermore, written down five times and more were these six expressions: interesting, fascinating, practical benefits found, motivating, develop soft skills, social life developed. Eventually, the expressions provided less than five times were the following: enthusiastic work, passionate, new things to learn, educational, great diversity of play genre, wonderful, special happiness, beautiful time, outsiders can join and be treated well, voluntary activity, creative, an extremely useful playground, increasingly attractive, significant, more mature thoughts, get experienced, learn how to work carefully, more open-minded, positive thinking way. 


\section{Table 17}

Suggestions for future Theater in Education programs

\begin{tabular}{|l|c|}
\hline \multicolumn{1}{|c|}{ Suggestions } & Rate of frequency \\
\hline Activity be expanded & 25 \\
\hline Activity be maintained & 16 \\
\hline More financial support from HCMCOU & 14 \\
\hline More time to prepare & 10 \\
\hline
\end{tabular}

Source: The researcher's data analysis

The participants' suggestions for future Theater in Education programs at HCMCOU are recorded in table 17. While sixteen participants suggested maintaining the Theater in Education method in English and American Literature classes, twenty-five of them proposed expanding it. In the matter of assistance for the realization and development of future Theater in Education programs at $\mathrm{HCMCOU}$, ten respondents called for more time to do necessary preparations for the performances and fourteen mentioned more financial support from the school.

\section{Discussion}

The study has unfolded the similarities and differences between the benefits and challenges of the use of the drama project or the Theater in Education method in language classes globally reported in the existing literature and the empirical perceptions of the merits and difficulties of the Theater in Education method of the students taking part in a Theater in Education project at the Faculty of Foreign Languages of HCMCOU in Vietnam.

\section{Benefits}

As regards linguistic knowledge and skills, the findings of this study confirm that the students who have participated in a Theater in Education project improve their pronunciation and intonation, speaking, writing, reading, vocabulary, and grammar as Fonio and Genicot (2011), Giebert (2014), Wessels (1987), and Whiteson (1996) outline. It is during the course of the preparations for the final production of the program that the improvements take place in practice.

In terms of social competences, development of teamwork, knowledge of culture, and empathy mentioned by Carson (2012), Giebert (2014), Gualdron and Castillo (2018), Marjanovic-Shane (1997), Ronke (2004), and Scheutz and Colangelo (2004) are found in the perceptions of the participants of this study. What should be noticed is teamwork was predominant in the students' minds. Differently, knowledge of culture that helps to develop intercultural competence and empathy gained by exploring and acting the fictional characters of the play that contributes to the development of humanity was given little recognition.

In the matter of psychological effects, pride, confidence, and motivation spoken well of in Marjanovic-Shane (1997), Ronke (2004), Scheutz and Colangelo (2004), and Yoshida 
(2007) are present in the data of this study. In addition, a heightened awareness of the potential to do the improbable and psychological development in a positive manner reported by those researchers was also expressed in the statements of the participants about their strength to work under pressure and the control of temper and emotion in working with their groupmates.

Relating to social life, the establishment of friendships and great joy in a memorable learning experience that Boudreault (2010), Šmardová (2008), and Wessels (1987) discuss were repeatedly applauded in the responses of the participants. Such expressions as expansion of relationships, made friends with more people, most meaningful time, interesting, wonderful, beautiful time, memorable, special happiness, and the like were numerous in the completed questionnaires of this study.

To do with the growth of diverse individual interests and talents, there are matches between the existing literature reviewed and the data collected for this study. What is found in Boudreault (2010), Giebert (2014), Ronke (2004), Scheutz and Colangelo (2004) are what is noticed in the data analysis of the study as the participants listed the beneficial effects they perceived in the fields of marketing, acting, handicraft, music appreciation, computer skills, creativity, etc. Again, there is, however, an imbalance within this cluster of assorted benefits. The perceptions of the development of the other competencies were noticeably dominated by those of marketing and acting.

\section{Challenges}

On the subject of challenges, identification of conflicts in group work that are, according to Carson (2012), inevitable is a single parallel that is drawn out. What is worth paying attention to is a heavier workload that is described as a challenge in a drama project by Nha (2009), Ronke (2004), and Wessels (1987) was considered a problem to complain about by only one out of 121 participants. Meanwhile, for the rest of the participants, that they worked harder and longer hours was recognized as a problem-solving strategy, not a problem to make complaints about, to deal with the demanding tasks during the preparations for the final productions.

On the other hand, while Šmardová (2008) and Wessels (1987) call attention to the students' skeptical attitude towards the drama project and Fonio and Genicot (2011) remark their irritation of the corrections of their mispronunciations during the rehearsals and their impatience of the repetitions of the lines of the characters, these challenges were not reflected in the study. It was because the participants had witnessed and been convinced by the previous generation students' successful Theater in Education programs that had widely captured the media in three languages (Vietnamese, English, French) and excited the public. Below are the links to the articles about the Theater in Education programs prior to "THEATER IN EDUCATION: English and American Literature Classes' Performances, 2017”:

- http://english.thesaigontimes.vn/47673/University-students-to-perform-plays-inEnglish.html

- http://vietnamnews.vn/life-style/297818/english-language-plays-staged-inhemc.html

- http://english.thesaigontimes.vn/47860/ Students-stage-Atonement-in-English.html 
- http://vietnamnews.vn/sunday/features/ 298193/teachers-innovative-approach.html

- http://english.thesaigontimes.vn/50632/ Shakespeare-Lives-in-Saigon.html

- http://english.thesaigontimes.vn/51438/-Open-University-hosts-drama-week-inEnglish.html

- http://english.thesaigontimes.vn/53940/-University-students-to-stage-dramas-inEnglish.html

- https://www.lecourrier.vn/le-theatre-au-service-des-etudiants/410873.html https://www.lecourrier.vn/le-theatre-pour-apprendre-une-langue-etrangere/309470.html

- http://baobinhduong.vn/kich-noi-bang-tieng-anh-san-choi-thu-vi-cua-sinh-vientruong-dh-mo-tp-ho-chi-minh-a142662.html

- http://nld.com.vn/van-hoa-van-nghe/romeo-va-juliet-hon-nhau-tren-duong-sach20161105161148278.htm

- https://thoibao.today/paper/dien-kich-shakespeare-tai-duong-sach-1309010 http://www.giaoduc.edu.vn/dem-kich-tieng-anh-den-duong-sach.htm

- http://thanhnien.vn/gioi-tre/sinh-vien-dien-kich-bang-tieng-anh-de-hoc-van777488.html

- http://nld.com.vn/van-hoa-van-nghe/kich-van-hoc-gay-xuc-dong-tren-san-dien-hocduong-20161219220104217.htm

- http://www.giaoduc.edu.vn/sinh-vien-dien-kich-gioi-tinh-xoa-bo-dinh-kien.htm

- http://nld.com.vn/van-hoa-van-nghe/cam-dong-khi-xem-kich-ve-nguoi-chuyen-gioidau-tien-20170521075247882.htm

- http://baotintuc.vn/giao-duc/loi-cuon-sinh-vien-hoc-ngoai-ngu-bang-san-khau-hoanhung-vo-kich-tieng-anh-20170522191114718.htm

It demonstrates the point Wessels (1987) advances that the skeptical students are convinced of the beneficial effects of the method by the successes the volunteer students have made.

Furthermore, as they asserted, joining the program was a very enjoyable learning experience. So the hardship they experienced was, consequently, outweighed by what they designated a unique experience or most meaningful time and the like. Actually, while their ten plays were still going on, several newspapers were already carrying articles about them. Here are the links to the articles about the performances of "THEATER IN EDUCATION: English and American Literature Classes' Performances, 2017' during the course of the program:

- http://english.thesaigontimes.vn/57340/University-students-to-stage-dramas-inEnglish.html

- https://thanhnien.vn/van-hoa/sinh-vien-dien-kich-tieng-anh-lan-gio-thanh-xuan-thoivao-kich-noi-911450.html 
- http://dantri.com.vn/van-hoa/bat-ngo-voi-kich-tieng-anh-mien-phi-ve-o-gan-photay-20171204102634402.htm

Last but not least, as Yoshida (2007) emphasizes a considerable challenge of the requirements on the teacher who is in charge of a drama project, it is imperative that he be, according to Šmardová (2008) and Wessels (1987), enthusiastic and meticulous in organizing diversified activities with his willingness. Moreover, Gaudart (1990), Giebert (2014), and Royka (2002) maintain that the teacher should have been familiarized with or trained in the method. In the data of the study, nonetheless, no participants had a word about difficulties deriving from the teacher's inadequate quality or behavior in guiding them to successfully complete the program although the questionnaires were completed anonymously. It can be inferred that the teacher - in this case meaning I, the researcher - met the requirements of a language teacher who is capable of applying the Theater in Education method into a foreign language - in this case meaning English - classes.

\section{Implications}

On personal level, this study enables me to get an insight into my own application of the Theater in Education method in my classes of English and American literature at the Faculty of Foreign Languages of HCMCOU with respect to the positive effects and the matters my students have experienced by learning the students' ideas (and those of their friends who have participated in the program) about them. This insightful knowledge is motivating and helpful to me, a lecturer who has been pioneering this method to such an extent in Vietnam. As a result, I will be more confident to advance the use of this method and more practically knowledgeable to better it in my future teaching practices at HCMCOU.

On local level, the analysis of the responses collected from the participants of this study suggests that the Theater in Education method has been highly appreciated by the students majoring in English at the Faculty of Foreign Languages of HCMCOU. On this account, it is likely to be welcomed as well by the students majoring in the other languages, namely Japanese and Chinese, at the Faculty of Foreign Languages at HCMCOU, on the one hand. On the other hand, in the non-major English classes of the other faculties, this method is also possibly applicable if it is open to the students' choice as two out of the four outsiders in the participants of this study were not majoring in English language at their universities. Moreover, based on learner-centeredness, HCMCOU could consider more funding for the promotion of the Theater in Education method as requested by the participants of this study.

On national scale, the findings of this study would be, hopefully, encouraging and inspirational to those Vietnamese teachers of English who are considering the adoption of this method in their teaching contexts in other universities. If a lecturer at HCMCOU can successfully apply the Theater in Education method in his classes with such positive effects mentioned above, then undoubtedly so can they.

And on global scale, eventually, since the empirical studies intended to directly and specifically investigate the benefits and issues of the utilization of the very Theater in Education method in language teaching, in my personal observation, have still been in relatively short supply, this research potentially makes contribution to the existing limited literature on the 
beneficial impacts and troublesome consequences of the use of the Theater in Education method in teaching foreign languages in general and teaching English as a foreign language in particular.

\section{Conclusion}

This study has brought about the answer to the research question "Did the students participating in the drama program 'THEATER IN EDUCATION: English and American Literature Classes' Performances, 2017' at HCMCOU in Vietnam perceive the benefits and challenges of the use of the Theater in Education method as demonstrated in previous research in the field of foreign language learning?" The contents of the answer include similarities to, on the one hand, and differences from, on the other hand, what previous research studies have mentioned. Those similarities and differences have been then discussed in detail. Hopefully, those interested in the adoption of the Theater in Education method in foreign literature classes at the faculty of foreign languages at a university may find the findings and discussions of this study informative to their interests.

\section{References}

Aita, S. (2009). The Theatre in Language Learning (TiLL) model: Exploring theatre as pedagogy in the L2 environment. Scenario, 3(1), 64-80.

Allen, G., Allen, I., \& Dalrymple, L. (1999). Ideology, practice and evaluation: Developing the effectiveness of theatre in education. Research in Drama Education, 4(1), 21-36.

Boudreault, C. (2010). The benefits of using drama in the ESL/EFL classroom. The Internet TESOL Journal, 16(1).

Carson, L. (2012). The role of drama in task-based learning: Agency, identity and autonomy. Scenario, 6(2), 47-60.

Dodson, S. L. (2000). FAQs: Learning languages through drama. Texas Papers in Foreign Language Education, 5(1), 129-141.

Fonio, F., \& Genicot, G. (2011). The compatibility of drama language teaching and CEFR objectives - Observations on a rationale for an artistic approach to foreign language teaching at an academic level. Scenario, 5(2), 75-89.

Fujita, S. (2008). A study of the effects of foreign language theater: Investigating a comprehensive approach to foreign language learning. Ann Arbor, MI: Proquest, Umi Dissertation Publishing.

Gaudart, H. (1990). Using drama techniques in language teaching. In A. Sarinee (Ed.), Language teaching methodology for the nineties (pp. 230-249). Singapore: SEAMEO Regional Language Centre.

Giebert, S. (2014). Drama and theater in teaching foreign languages for professional purposes. Recherche et Pratiques Pédagogiques en Langues de Spécialité, 33(1), 138-150. 
Gualdron, E., \& Castillo, E. (2018). Theater for language teaching and learning: The E theater, a holistic methodology. Profile: Issues in Teachers' Professional Development, 20(2), 211-227.

Marjanovic-Shane, A. (1997). Play and theater in education. Journal of Russian \& East European Psychology, 35(3), 3-9.

Nha, V. T. T. (2009). Using a drama project to give students opportunities to be communicative. Paper presented at the $5^{\text {th }}$ National VTTN ELT Conference, Hanoi.

Ronke, A. (2004). Wozu all das theater? Drama and theater as a method for foreign language teaching and learning in higher education in the United States. Berlin, Germany: Technische Universität Berlin.

Royka, J. (2002). Overcoming the fear of using drama in English language teaching. The Internet TESL Journal, 8(6).

Scheutz, C. R., \& Colangelo, L. M. (2004). Full-scale theater production and foreign language learning. Foreign Language Annals, 37(3), 374-389.

Šmardová, L. (2008). Performance projects: An alternative to English language teaching (Bachelor's thesis, Masaryk University, Brno, Czech Republic). Retrieved October 20, 2018, from https://is.muni.cz/th/b8tgw/Performance_projects.pdf

Wessels, C. (1987). Drama. New York, NY: Oxford University Press.

Whiteson, V. L. (1996). New ways of using drama and literature in language teaching. Alexandria, VA: Teachers of English to Speakers of Other Languages.

Yoshida, M. (2007). Playbuilding in a Japanese College EFL classroom: Its advantages and disadvantages. Caribbean Quarterly, 53(2), 231-256. 